\title{
Comparative morpho-anatomical studies of the lesions caused by citrus leprosis virus on sweet orange
}

\author{
JOÃO P.R. MARQUES ${ }^{1}$, ELLIOT W. KITAJIMA ${ }^{2}$, JULIANA FREITAS-ASTÚA ${ }^{3}$ \\ and BEATRIZ APPEZZATO-DA-GLÓRIA ${ }^{4}$ \\ ${ }^{1}$ Programa de Pós-graduação em Fisiologia e Bioquímica de Plantas, Laboratório de Anatomia Vegetal \\ Escola Superior de Agricultura "Luiz de Queiroz", USP, Av. Pádua Dias, 11, 13418-900 Piracicaba, SP, Brasil \\ ${ }^{2}$ Departamento de Entomologia e Acarologia, Escola Superior de Agricultura “Luiz de Queiroz”, USP \\ Av. Pádua Dias, 11, 13418-900 Piracicaba, SP, Brasil \\ ${ }^{3}$ Embrapa Mandioca e Fruticultura Tropical, Rua Embrapa s/n, 44380-000 Cruz das Almas, BA, Brasil \\ ${ }^{4}$ Departamento de Ciências Biológicas, Laboratório de Anatomia Vegetal \\ Escola Superior de Agricultura “Luiz de Queiroz”, USP, Av. Pádua Dias, 11, 13418-900 Piracicaba, SP, Brasil \\ Manuscript received on October 21, 2008; accepted for publication on August 27, 2009
}

\begin{abstract}
The leprosis disease shows a viral etiology and the citrus leprosis virus is considered its etiologic agent. The disease may show two types of cytopatologic symptom caused by two virus: nuclear (CiLV-N) and cytoplasmic (CiLV-C) types. The aim of this study was to compare the morpho-anatomical differences in the lesions caused by leprosis virus-cytoplasmic and nuclear types in Citrus sinensis (L.) Osbeck 'Pêra'. Leaf and fruit lesions were collected in Piracicaba/São Paulo (cytoplasmic type) and Monte Alegre do Sul/São Paulo and Amparo/São Paulo (nuclear type). The lesions were photographed and then fixed in Karnovsky solution, dehydrated in a graded ethylic series, embedded in hydroxy-ethyl methacrylate resin (Leica Historesin), sectioned ( $5 \mu \mathrm{m}$ thick), stained and mounted in synthetic resin. The digital images were acquired in a microscope with digital video camera. Leaf and fruit lesions caused by the two viruses were morphologically distinct. Only the lesion caused by CiLV-N virus presented three well-defined regions. In both lesions there was the accumulation of lipidic substances in necrotic areas that were surrounded by cells with amorphous or droplets protein. Only leaf and fruit lesions caused by CiLV-N virus exhibited traumatic gum ducts in the vascular bundles.
\end{abstract}

Key words: anatomy, hyperplasy, hypertrophy, traumatic gum ducts.

\section{INTRODUCTION}

Citrus leprosis is a viral disease of significant economic relevance due to the economic losses it causes, in some cases leading to plant weakening, premature fruit drop and, when the plant presents intense infection, the disease can lead to the plant death (Bitancourt 1955, Rodrigues et al. 2003b).

According to Bastianel et al. (2006), electron microscopic studies supported by molecular analyses re-

Correspondence to: Dr. Beatriz Appezzato-da-Glória E-mail: bagloria@esalq.usp.br vealed that leprosis symptoms may be caused by two distinct viruses, both transmitted by the tenuipalpid mite Brevipalpus (Rodrigues et al. 2003b, Bastianel et al. 2006). The nuclear type (CiLV-N), first described by Kitajima et al. (1972), with short rod-shaped particles and occurring in the nucleoplasm or cytoplasm, is usually connected perpendicularly to the membranes (endoplasmic reticulum or nuclear envelope), including a nuclear viroplasma. The cytoplasmic type (CiLV-C), as described by Colariccio et al. (1995), with short bacilliform particles, provided with a membrane and occurring in the lumen of the endoplasmic reticulum with 
an electron-dense and vacuolated mass (viroplasm), appears within the cytoplasm.

CiLV-C is widespread and prevails in nearly all samples assessed in Brazil, Argentina, Costa Rica, Panama, Colombia, Bolivia and Guatemala, while CiLV$\mathrm{N}$ is rarely found and seems to occur associated with lower temperatures. It was found in Panama and in some cities of the state of São Paulo (Amparo, Monte Alegre do Sul, Santo Antonio da Posse, Serra Negra and São Roque), Rio Grande do Sul, (Marquês de Souza) and Minas Gerais (Andradas) (Kitajima et al. 2004, Freitas-Astúa et al. 2004, Chagas et al. 2006). Recently, CiLV-N and CiLV-C have been demonstrated to be distinct viruses by molecular assays, since the primer pairs designed to amplify each of the CiLV-C ORFs and unstranslated regions failed to detect CiLV-N (FreitasAstúa et al. 2005). From the morphologic and cytopathologic viewpoints, the CiLV-N is similar to Orchid fleck virus (OFV) and may belong to the recently proposed genus Dichorhabdovirus, within the family Rhabdoviridae for OFV (Kondo et al. 2006).

Because of the morphological similarity with rhabdoviruses, CiLV-C was initially considered as a possible member of this family. However, after the complete sequencing of its genome (Pascon et al. 2006) whose organization is distinct from other known viruses, a new genus Cilevirus has been proposed to accommodate this virus (Locali-Fabris et al. 2006).

One of the characteristics of citrus leprosis and other Brevipalpus mite-transmitted viruses is the localized symptoms the virus induces in infected tissues (leaf, stem, flower or fruit), which do not become systemic as they occur in most of the plant virus infections. Marques et al. (2007) studied the anatomical changes caused by CiLV-C in leaf and fruit tissues, and associated some of them with the possible mechanisms that may prevent the virus from becoming systemic. Such alterations include parenchyma cell hypertrophy, hyperplasy, and the accumulation of lipidic compounds. Similar changes were also noticed in leaf tissues infected by OFV (K.S. Kubo, unpublished data). However, the causes for such pathological alterations remain to be explained.

It has been noticed that lesions caused by CiLV-C and CiLV-N in sweet orange (Citrus sinensis (L.) Osbeck) leaves, though similar, present subtle differences.
Those induced by CiLV-C tend to grow larger, usually with a pale green color, and show one or more concentric brownish rings containing gum material, while lesions caused by CiLV-N tend to be smaller, with a dark necrotic center and a chlorotic halo (Bastianel et al. 2006).

In this communication we report the morpho-anatomical changes in the leaf and fruit lesions caused by CiLV-N and by CiLV-C from the field, and discuss the results comparing these changes with the alterations observed previously with CiLV-C (Marques et al. 2007).

\section{MATERIALS AND METHODS}

\section{Plant Material}

Sweet orange (Citrus sinensis (L.) Osbeck) cv. 'Pêra' leaves and fruits presenting cytoplasmic-type leprosis symptoms were collected from the Citrus Collection of the Plant Production Department of the Escola Superior de Agricultura "Luiz de Queiroz" (ESALQ), Piracicaba, São Paulo State. C. sinensis leaves and fruits with symptoms caused by CiLV-N were obtained from orange orchards in the municipalities of Monte Alegre do Sul and Amparo, in São Paulo State. The average annual temperature of the cities of Amparo and Monte Alegre do Sul is $21.0^{\circ} \mathrm{C}$ and $20.8^{\circ} \mathrm{C}$, respectively, while in Piracicaba is $21.6^{\circ} \mathrm{C}$. According to Bastianel et al. (2006), the mild climate may favor the presence of CiLV-N. The lesions (four of each type) were collected according to morphology and size.

The identity of the causal viruses (CiLV-C and CiLV-N) was previously determined by RT-PCR using primers specific for CiLV-C (Locali-Fabris et al. 2006) and a transmission electron microscopy to verify the cytopathic effects in the tissues of the lesion (Kitajima et al. 2003, Rodrigues et al. 2003b).

\section{METHODS}

\section{MORPHO-ANATOMICAL ANALYSES}

Samples of $C$. sinensis leaves, fruits and branches, exhibiting lesions caused by CiLV-C or CiLV-N at different stages, as well as the corresponding uninfected, healthy control materials, were collected and fixed in a modified Karnovsky solution $-2.5 \%$ glutaraldehyde, $2 \%$ paraformaldehyde in $0.1 \mathrm{M}$ phosphate buffer $\mathrm{pH}$ 7.2 (Karnovsky 1965) by 3-4 days at room temperature. 
For a better fixation, these samples were submitted to a vacuum to remove air from the tissues. After fixation, samples were dehydrated in a series of increasing concentration of ethanol and embedded in a hydroxyethyl methacrylate resin (Leica Historesin). The blocks were sliced in a Leica RM 2045 rotary microtome to produce $5-7 \mu \mathrm{m}$ thick sections. Sections were mounted on glass slides and stained with 1\% Toluidine Blue (Sakai 1973) for histological analyses. Sudan Black B was used to detect lipidic substances (Pearse 1968). Detection of phenolic substances was made with Ferric Chloride (Johansen 1940) and by metachromasy of Toluidine Blue (Rodrigues et al. 2003a). Starch was identified by Iodized Zinc Chloride (Jensen 1962); Aniline Blue Black (Fisher 1968) and Xylidine Ponceau (Cortelazzo 2007) were employed to identify protein compounds. Pectic compounds were detected by Ruthenium Red (Chamberlain 1932). After staining, the sections were mounted on Entellan ${ }^{\circledR}$ synthetic resin. Examinations were made in a Leica DMLD light microscope equipped with a Leica DC 300F camera for digital images.

\section{RESULTS}

\section{Healthy Tissues}

The citrus leaf anatomy presents an unisseriated epidermis covered by a thick cuticle. The mesophyll is composed by two or three layers of palisade parenchyma cells, and by 8-9 layers of spongy parenchyma cells. Lysigenous cavities occur in the mesophyll (Schneider 1968).

The citrus fruit presents an exocarp, or flavedo (yellow tissue), constituted of a cuticle-covered outer epidermis and a compact subepidermal parenchyma with oil glands. The mesocarp, or albedo (white tissue), consists of parenchyma with large intercellular spaces and cells with armlike extensions (Esau 1977).

\section{Morphological AnAlysis of LeAf Lesions}

The samples collected at Monte Alegre do Sul and Amparo had a similar leaf morphology. The lesions caused by CiLV-N on the leaves were smaller and in a larger number (Fig. 1A) than those induced by CiLV-C (Figs. $2 \mathrm{~A}$ and $\mathrm{B})$.
Mature lesions caused by CiLV-N were characterized by the presence of three distinct regions: necrotic center, orange-colored intermediate halo, and outer chlorotic halo (Figs. 1B and 1G). A slight decrease in the thickness of the leaf blade was observed in the necrotic center, while in the intermediate halo the thickness increased (Fig. 1B). In some cases, the necrotic central region of the lesion spread along the midvein and, or the secondary veins of the leaves.

Unlike the lesions caused by CiLV-N, the CiLV$\mathrm{C}$ lesions were characterized by successive depressed necrotic halos (Fig. 2B) or by necrotic spots, alternating with chlorotic regions. Both lesions presented an outer chlorotic halo at the boundary of the lesion (Figs. $1 \mathrm{~B}$ and $2 \mathrm{~B}$ ), which, however, was more evident in the lesions caused by CiLV-N (Fig. 1C).

The evolution of the leaf lesions in 'Pêra' sweet orange infected by CiLV-N are shown in Figures $1 \mathrm{C}$ to $\mathrm{F}$. The lesion began as a necrotic spot (Fig. 1C), achieving a larger diameter due to the increase of the necrotic region and the presence of the outer chlorotic halo (Fig. 1D). On the following stage, the beginning of the intermediate halo formation could already be seen (Fig. 1E), which gradually expanded (Fig. 1F).

\section{Anatomical Analysis of Leaf Lesions}

All regions described for the lesion caused by CiLV$\mathrm{N}$ (Fig. 1G) and CiLV-C (Figs. 2D and H) presented anatomical differences. At the border of the mature lesion (outer chlorotic halo), the mesophyll cells were plasmolyzed (Fig. 1H). The same was observed for the lesions caused by CiLV-C (Fig. 2L). In the orangecolored intermediate halo, in the lesion caused by CiLV-N, the thickness of the leaf blade increased due to intense hypertrophy and hyperplastic activity of the spongy parenchyma cells (Fig. 1J), especially in the areas associated with the vascular bundle (Fig. 1K). The same was observed in the lesions caused by CiLV-C (Figs. 2E-F and I). The spongy parenchyma cells above the vascular bundles divided periclinally (Fig. 2E-F), and the cells above this division area accumulated lipidic compounds (Fig. 2G). In the case of the lesions caused by CiLV-N, the hyperplasia also results in the elevations of the mesophyll as occur with the CiLV-C (Fig. 2E). 


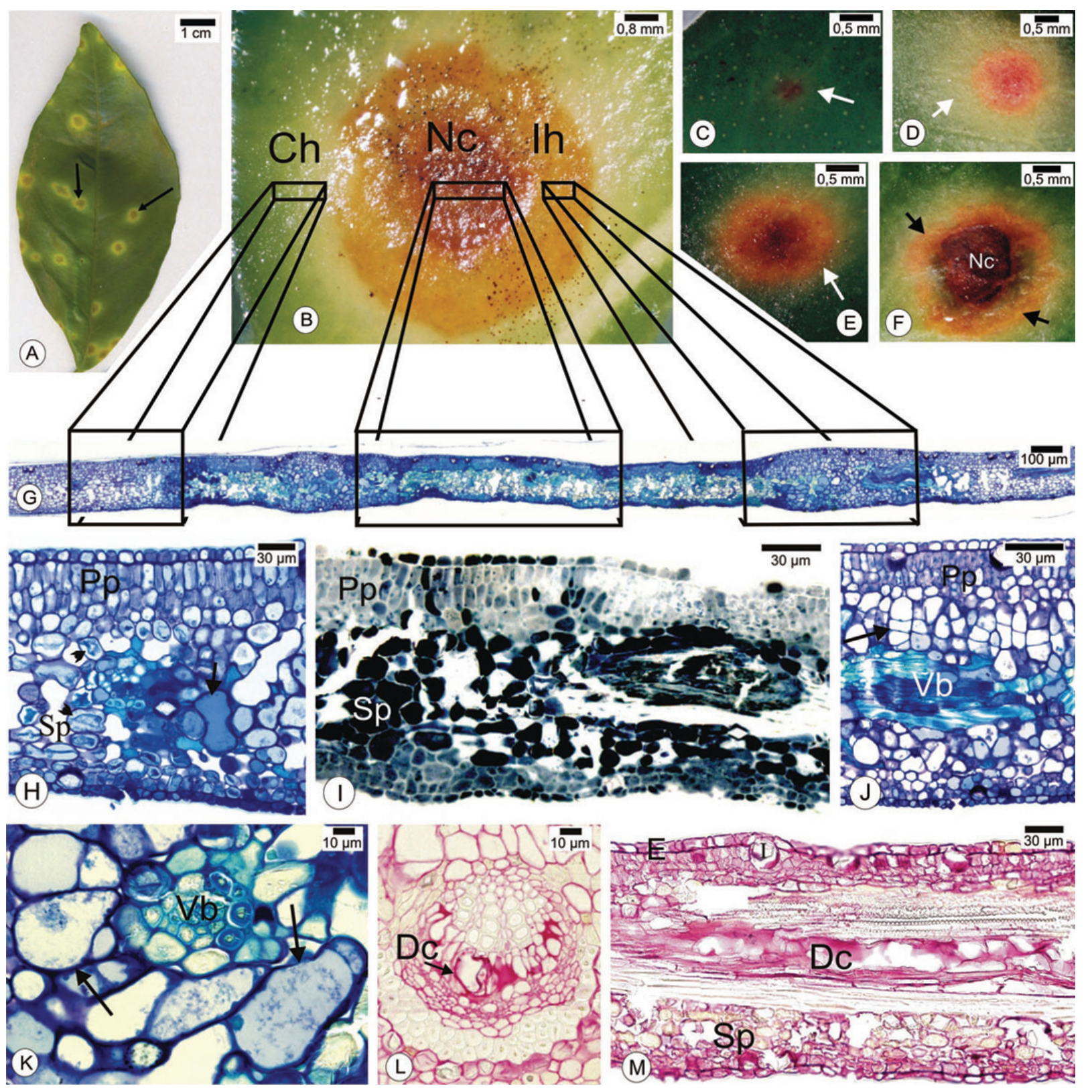

Fig. 1 - Leaf lesions caused by CiLV-N in Citrus sinensis (L.) Osbeck 'Pêra'. Sections stained with Toluidine Blue (G,H,J,K); Sudan Black B (I) and Ruthenium Red (L,M). A. Overview of injured leaf. B. Typical lesion showing all three regions. C-F. Stages of lesion formation. The arrows indicate the rise of the intermediate halo. G. Cross section of the lesion with each rectangle corresponding to the region indicated in B. H. Chlorotic halo region. Notice the plasmolysis in the spongy parenchyma (arrowheads) and hipertrofied cell (arrows). I. Necrotic center of the lesion. J-K. Intermediate halo region. J. Hyperplasia (arrow) of cells above the vascular bundle. K Hypertrophy (arrows) in vascular bundle sheath cells. L-M. Detail of intermediate halo shows in the vascular bundles in cross (L) and longitudinal (M) sections of traumatic gum ducts (Dc). Ch - Chlorotic halo; E - Epidermis; Ih - Intermediate halo; Nc - Necrotic center Pp - Palisade parenchyma; Sp - Spongy parenchyma; Vb - Vascular bundle. 

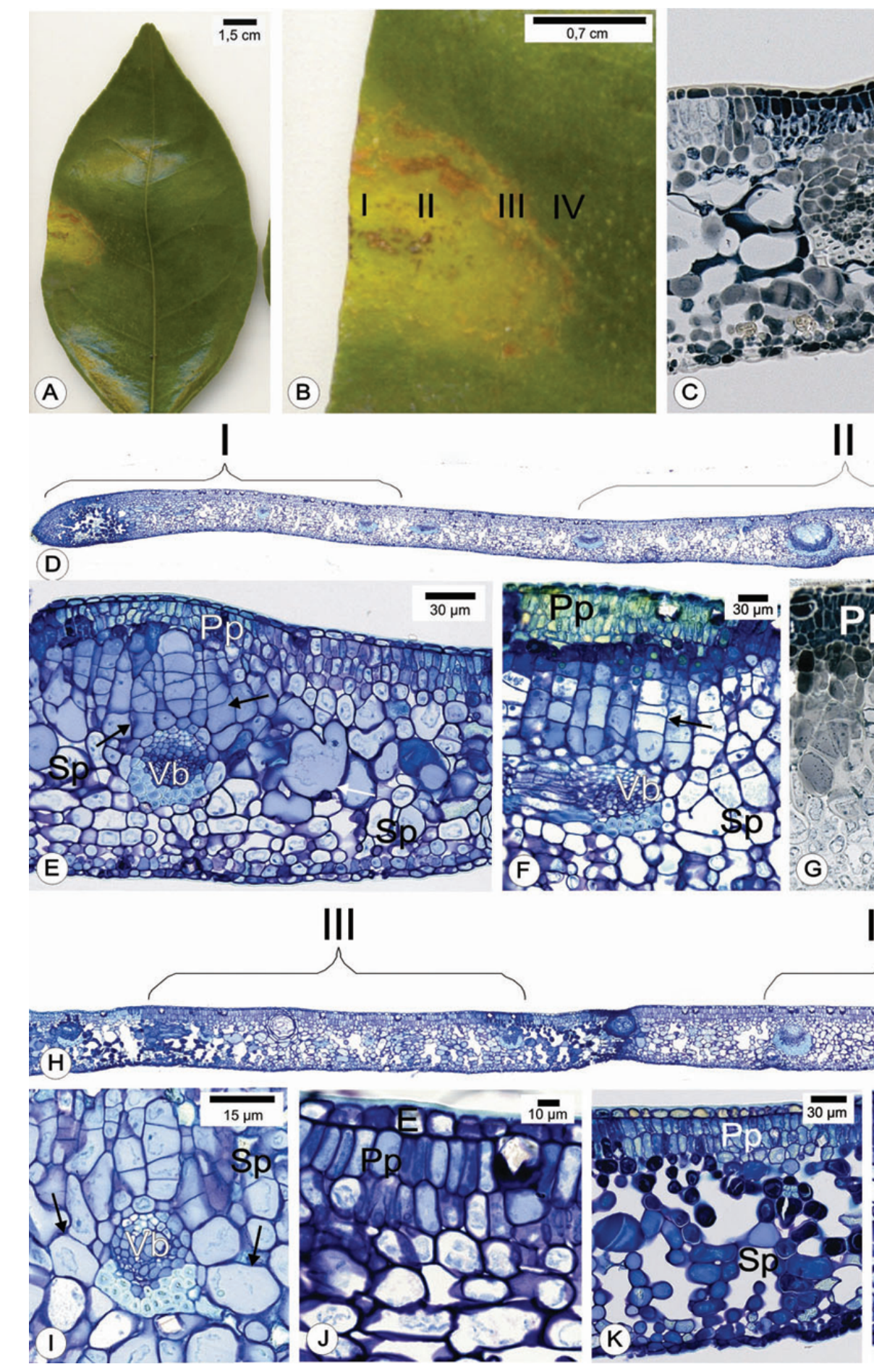
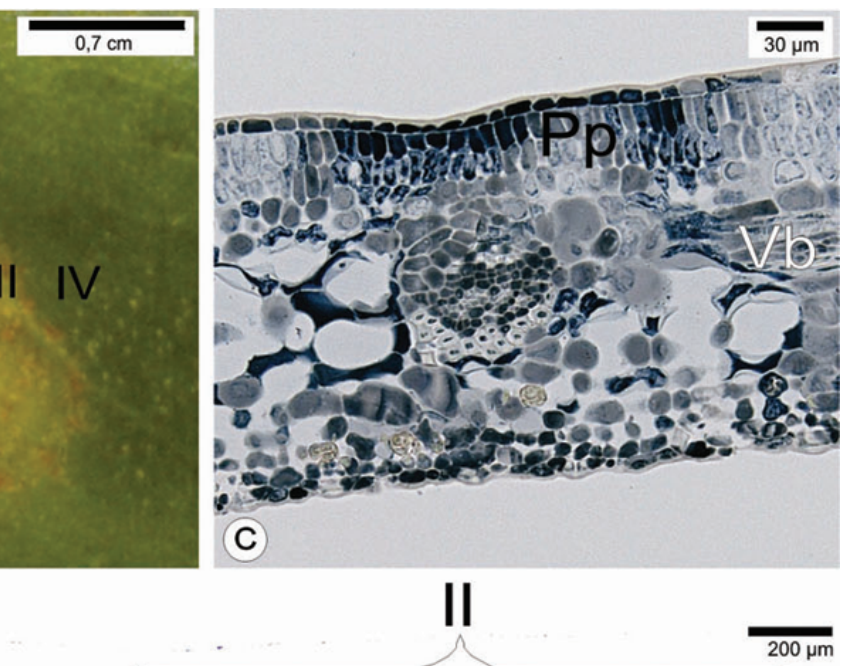
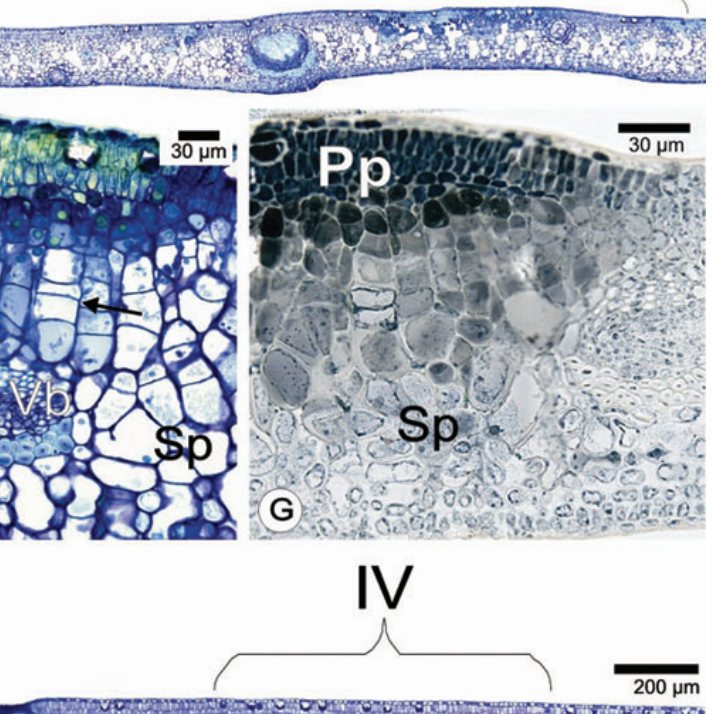

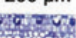
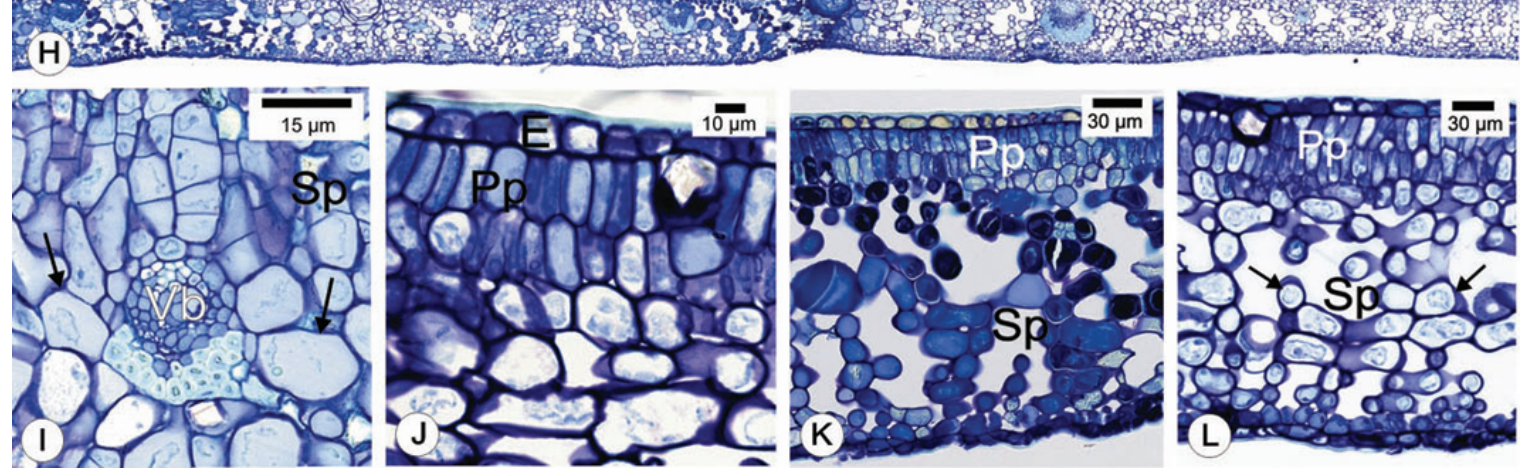

Fig. 2 - Cross sections (A-E, H-M) and morphology (F-G) of the leaf lesions caused by CiLV-C in Citrus sinensis (L.) Osbeck 'Pêra'. Figure C corresponds to sector I indicated in B and D. Figures E-G and I-J correspond to sectors II, and K-L correspond to sectors III and IV, respectively. Figures D and $\mathrm{H}$ are cross sections of the lesion shown in B with the corresponding sectors I to IV. C and G. Lipid content (blackish region). E-F. Hyperplasia (black arrows) and hypertrophy (white arrow in E) of spongy parenchyma cells. In I there is the hypertrophy of bundle sheat cells (arrows). K. Necrosed cells. L. Plasmolysed cells (arrows) E - Epiderm; Vb - Vascular bundle; Sp - Spongy parenchyma; Pp - Palisade parenchyma. 
In cases of injuries caused by CiLV-C, there is a region with successive necrotic halos (Fig. 2B). In this region, the mesophyll cells are necrotic (Fig. 2K) and can accumulate lipidic compounds.

At the central region of the lesion caused by CiLV-C, the palisade parenchyma cells appeared devoid of chloroplasts (Fig. 2J). In the lesion caused by CiLV-N, cells accumulating protein compounds were observed in the interface between the hyperplastic cells and necrotizing cells of the necrotic center. The necrotic center (Fig. 1I) was constituted by chlorophyllian parenchyma cells, especially the spongy type, and vascular ones, which accumulated lipidic compounds. The lipidic accumulation was also verified in the necrotic halos of the lesions caused by the CiLV-C (Figs. 2C and G).

A decrease in the amount of starch grains content in the cells was observed in all leaf lesions caused by citrus leprosis, either nuclear or cytoplasmic type. Phenolic compounds were not observed in our histological preparations.

Only in the leaf lesions caused by CiLV-N were observed traumatic gum ducts in the vascular bundles (Figs. 1L and M).

\section{Morpho-ANATOMiCAl ANALysis of Fruit LEsions}

Though apparently similar, at close examination the lesions on the fruits caused by CiLV-C and CiLV-N were different regarding the number of lesions and appearance. Lesions in CiLV-N infected fruits (Fig. 3A) tended to be more numerous than those caused by CiLV-C (Fig. 4A). A possible evolution of the fruit lesion caused by CiLV-N is presented in the Figure 3C.

Both lesion types, CiLV-C and CiLV-N, began as a reddish spot in the pericarp surrounded by a discrete chlorotic halo. However, as the infection advances, differences in the morphology of the fruit lesions caused by CiLV-N and CiLV-C become evident (Figs. 3B and 4B). In the initial stage, both lesion types showed a necrotic center, an intermediate halo and a chlorotic halo, but in the lesions caused by CiLV-N the intermediate halo was reddish and the chlorotic halo was more intense (Fig. 3B), while in those caused by CiLV-C the intermediate halo was chlorophylled and enclosed by the necrotic halo, which in turns was enclosed by the chlorotic halo
(Fig. 4B). In the lesions caused by CiLV-C an additional halo was present, resulting in a larger size. In both cases, mature lesions presented a depression on the fruit surface at the central region.

Histological analysis of the lesions indicated that alterations in the epicarp and mesocarp were noticeable in the lesions caused by CiLV-C and CiLV-N at advanced stage (Figs. 3C-E and 4C and D). In the lesions caused by CiLV-C, the collapse of oil cavity (Fig. 4C) and intensive plasmolysis of the cells occurred in the epi- and mesocarp.

The center of both lesions has cells that accumulate lipid compounds (Fig. 3E) and it is surrounded by a layer of cells that accumulate lipid and protein droplets (Figs. 3F-G and 4E-F). The protein droplets occur in clusters or scattered (Fig. 3H-I).

Advanced stages of the lesions caused by CiLV-C revealed a layer of dividing cells in the boundary (Fig. 4D) between the lipid and protein accumulating regions, which is circumscribed in nearly the whole extension by lysed cells (Fig. 4C). The vascular bundle near the injuried area shows a great quantity of protein droplets (Fig. 4G).

In the case of lesions caused by CiLV-N, traumatic gum ducts were observed in the vascular bundles adjoining the injured area (Figs. 3J-L) and, in some sectors, the accumulation of pectic compounds occurred in the intercellular spaces (Fig. 3L).

\section{DISCUSSION}

A histological comparison of the leaf lesions caused by CiLV-C either from natural infection in the field in the present case or after experimental mite inoculation under laboratory conditions (Marques et al. 2007) revealed essentially the same pattern. However, significant differences were noticed when anatomical features of the leaf and fruit lesions caused by CiLV-C and CiLV-N are compared and must be the cause of the slight but noticeable differences in the external aspect of the leaf and fruit symptoms caused by these viruses.

The analysis of leaf lesions caused by CiLV-C proceedings of field indicated that there is one standard of lesions evolution in comparison to the samples that were submitted to inoculation (Marques et al. 2007). 

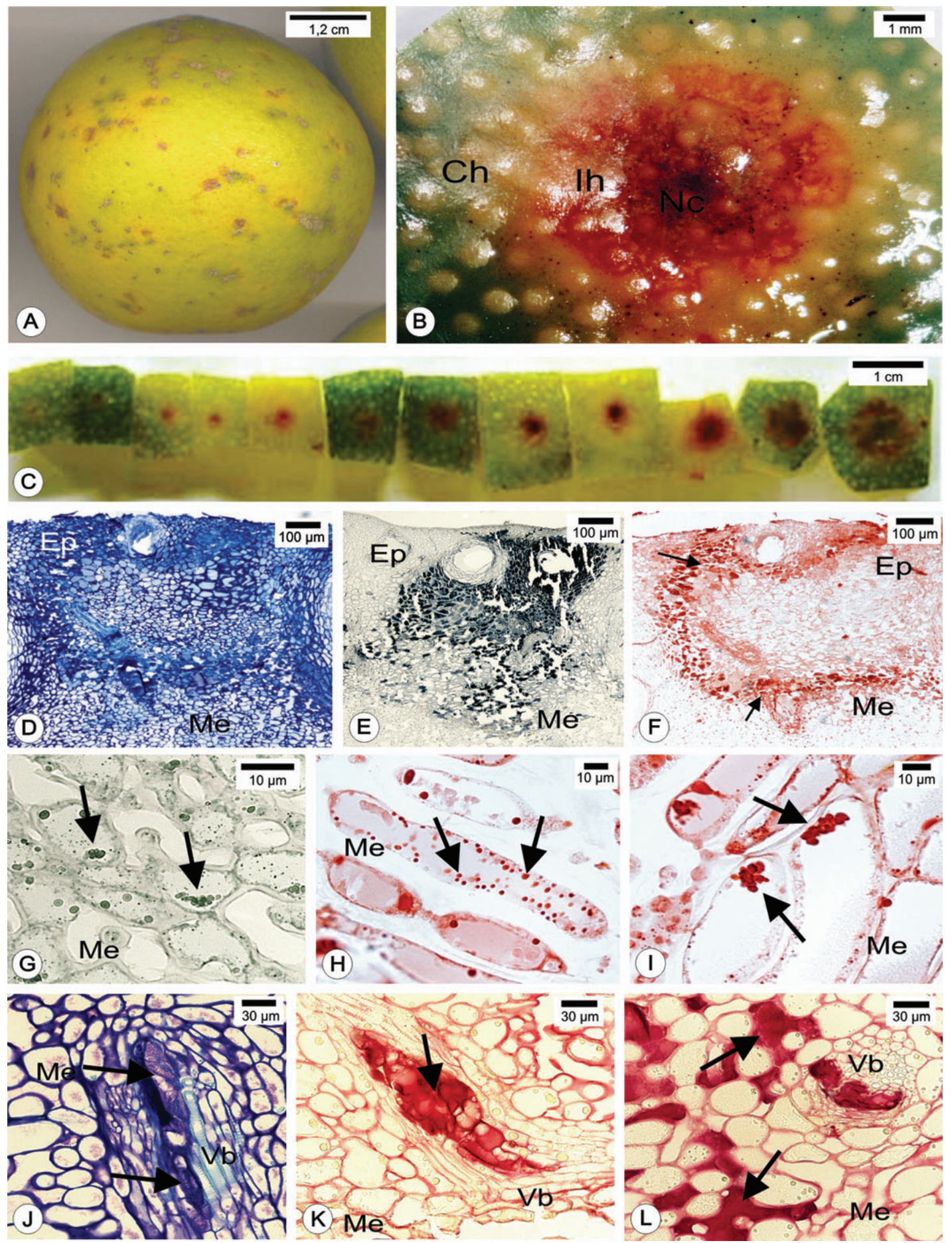

Fig. 3 - Fruit lesions caused by CiLV-N in Citrus sinensis (L.) Osbeck 'Pêra'. Sections stained with Ruthenium Red (K,L), Sudan Black B (E,G), Toluidine Blue (D,J) and Xylidine Ponceau (F,H,I). A. Overview of injured fruit. B. Typical lesion. Nc - necrotic center; Ih - intermediate halo; $\mathrm{Ch}$ - chlorotic halo. C. Possible evolution stages of the fruit lesions caused by CiLV-N. D-L. Cross sections of the lesion indicated in B. E an G. Cells with lipid content in the necrotic center (D) and lipid dropless (E) in the outer halo (arrows). F, H-I. Protein droplets within the cells. J-L. Traumatic gum duct (arrow) along the vascular bundle. L. Pectic substances in the intercellular spaces (arrows). Ep - Epicarp; Me - Mesocarp; $\mathrm{Vb}$ - Vascular Bundle. 

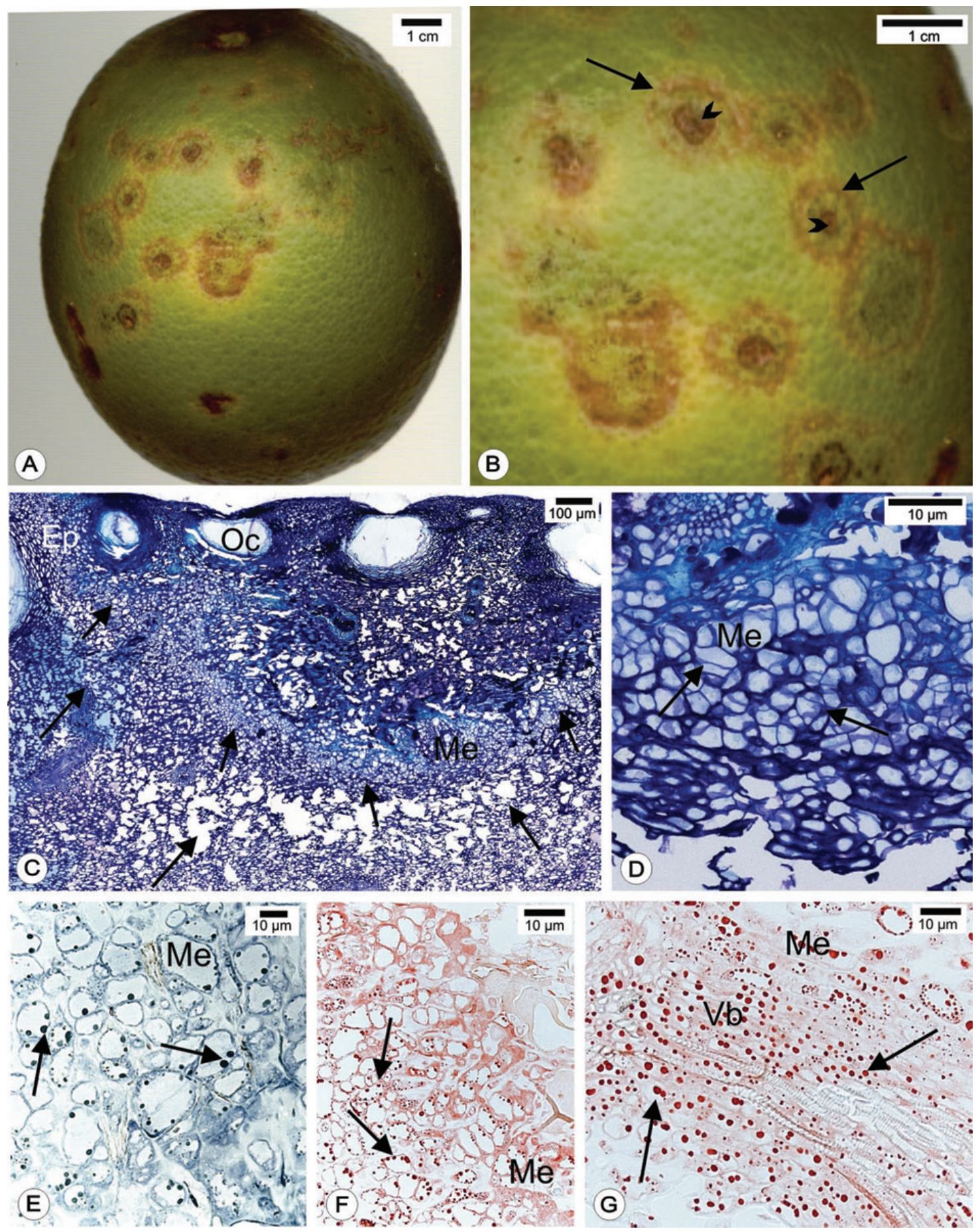

Fig. 4 - Lesions caused by CiLV-C in Citrus sinensis (L.) Osbeck 'Pêra' fruits. Sections stained with Sudan Black B (E) Toluidine Blue (C-D) and Xylidine Ponceau (F-G). A-B. Overview and detail of lesions in fruits. In B is verified that the lesions show necrotic halos (arrows) around the necrotic centers (arrowhead). C-J. Cross sections of the lesion. C. The oil cavities were collapsed. Lysis region (long arrows) and hyperplasia region (short arrows). D. Detail of the hyperplasia region showed in C. E. Lipid droplets (arrows). F. Details of the region with protein droplets (arrows). G. Droplets (arrows) in the vascular bundle (Vb); Ep - Epicarp; Me - Mesocarp; Oc - Oil cavity; Vb - Vascular Bundle. 
A characteristic plasmolysis in the cells of the outer halo occurs in the lesions caused by both types of leprosis. Similar plasmolysis caused the suppression of the lesion development in Vigna unguiculata plants inoculated with the tobacco necrosis virus as reported by Coutts (1978). Since the cell-to-cell spread of the infection of plant viruses is made through plasmodesmata (Gilbertson and Lucas 1996), plasmolyzed cell layers in the lesion border may represent one of the defense mechanisms of the plant tissue to restrict the spread of the infection. Oparka (1994) mentioned that plasmodesmata in plasmolized cells are obstructed because of the changes at the desmotubule region as a consequence of the retraction of the plasmatic membrane. In the lesions caused by CiLV-N, plasmolysis was noticed in the cells close to the necrotic lesion center, a likely initial inoculation site. This perhaps explains the smaller size of the lesions caused by this virus constraining the initial spread of CiLV-N. In the lesions caused by CiLV-C infection, such a plasmolysis seems to occur only at the edge of the lesions in a later stage, which explains why the lesions may expand more than those caused by CiLV-N.

It is remarkable that, in lesions caused by both CiLV-N and CiLV-C, hypertrophy and hyperplasy develop in parenchyma cells. This process may occur in tissues infected by other Brevipalpus-transmitted viruses, as noticed also in OFV-infected orchid leaves and in Clerodendrum with CLCSV (K. Kubo, unpublished data, R.T. Gomes, unpublished data). If such process is caused as a result of the infection process of the virus, a reaction of the plant tissues to the infection or by some substance injected by the mite during the feeding process has to be evaluated.

The lesions caused by CiLV-N in the intermediate halo region, a process referred to as gummosis (Fahn 1988), are present. On the other hand, traumatic gum ducts are consistently present in the stem tissues injured by CiLV-C (Marques et al. 2007). Gedalovich and Fahn (1985) describe the content of the gum produced in $\mathrm{Ci}$ trus stems injured by Phytophthora as a polysaccharide basically constituted by branched chains of galactose, with arabinose-bearing side branches or glucoronic acid. The same nature probably may be attributed to the gum accumulated in the lesions caused by CiLV-N or CiLV-
C. According to Fahn (1979), starch may be a source for gum formation, and we noticed that its level in infected tissues was lower than in healthy tissues probably due to the starch grains degradation. It is interesting to notice that the expression of a-amylase genes increases in lesioned tissues (Freitas-Astúa et al. 2007).

During a comparative study of leaf leprotic lesions and other types of lesions, such as those of the concentric ring blotch disease of South Africa, cell hypertrophy and necrosis were noticed in both cases. However, calcium oxalate crystals accumulation was noticed in intercellular spaces only in the lesions of concentric ring blotch disease (R.T. Gomes, personal communication) caused possibly by a virus transmitted by the eryiophyid citrus grey mite Calacarus citrifollii Keifer (Roussouw and Smith 1963). Such crystals are believed to play a role in the programmed cell death (Ceita et al. 2007) and were also reported in the stem lesions caused by CiLV-C (J.P.R. Marques, unpublished data).

The depression of the fruit skin tissue in the lesion was already suggested as a consequence of the collapse of underlying tissues by Bitancourt (1934) and confirmed in the present study. Hyperplastic activities in fruit parenchyma cells were noticeable only in the infection by CiLV-C.

Freitas-Astúa et al. (2007) reported the induction to gene expression for lipoxygenase enzyme (LOX) in CiLV-C-infected cells, which is correlated to polyunsaturated lipid biosynthesis (Feussner and Wasternack 2002); the intermediate products generated via lipoxygenase work in the plant defense system. Shah (2005) proposes that the metabolism of lipids plays a critical role in the pathogenesis and in the expression of defense responses in plants. It is possible that these lipid compounds present in the necrotizing tissues following CiLV-N or CiLV-C infection are involved in the plant defense mechanism following infection by these viruses, though there is no similar record for such a process in the literature.

The formation of protein clusters may be induced by oxidation, thermal stress and changes in the primary protein structure (Kopito 2000). In the lesions caused by $\mathrm{CiLV}-\mathrm{C}$, we noticed that lipid-containing regions are surrounded by a halo of cells that accumulated protein 
clusters, and this process may result from stresses caused by the viral infection.

\section{ACKNOWLEDGMENTS}

This work was supported by Fundação de Amparo à Pesquisa do Estado de São Paulo (FAPESP) (00/11805-0, 06/5492-6), Brazil.

\section{RESUMO}

A doença leprose dos citros tem etiologia viral sendo o citrus leprosis virus seu agente etiológico. Demonstrou-se que há dois vírus distintos que causam sintomas de leprose em citros: citoplasmático (CiLV-C) e o nuclear (CiLV-N). O objetivo desse estudo foi comparar as diferenças morfo-anatômicas nas lesões causadas por CiLV-C e por CiLV-N em laranjeira doce (Citrus sinensis (L.) Osbeck) 'Pêra'. As lesões foliares e dos frutos foram coletadas em Piracicaba/SP (tipo citoplasmático) e em Monte Alegre do Sul/SP e Amparo/SP (tipo nuclear). As lesões foram fotografadas e em seguida fixadas em solução Karnovsky, desidratadas em série etílica, incluídas em historesina e secionadas em micrótomo rotativo. As lâminas foram coradas, analisadas e fotografadas. As lesões foliares e do fruto causadas pelos dois vírus eram morfologicamente distintas. Somente a lesão causada por CiLV-N apresentou três regiões bem definidas. Em ambas as lesões ocorreu acúmulo de substâncias lipídicas nas áreas necrosadas que se achavam envoltas por células com conteúdo protéico amorfo ou em gotas. Somente as lesões da folha e do fruto causadas pelo CiLV-N exibiram ductos traumáticos gomosos nos feixes vasculares.

Palavras-chave: anatomia, hiperplasia, hipertrofia, ductos traumáticos gomosos.

\section{REFERENCES}

Bastianel M, Freitas-Astua J, Kitajima EW and MACHADO MA. 2006. The Citrus leprosis pathosystem. Summa Phytopathol 32: 211-220.

BITANCOURT AA. 1934. As manchas das laranjas: descrição das principais manchas, podridões e outras alterações das laranjas, e dos meios de combatê-las. São Paulo: Instituto Biológico, $135 \mathrm{p}$.

Bitancourt AA. 1955. Estudos sobre a leprose dos Citrus. I. Distribuição geográfica e sintomatologia. Arq Inst Biol 22: 161-184.
CEITA GO ET AL. 2007. Involvement of calcium oxalate degradation during programmed cell death in Theobroma cacao tissues triggered by the hemibiotrophic fungus Moniliophthora perniciosa. Plant Sci 173: 106-117.

Chagas CM, Colariccio A and Harakava R. 2006. Novos registros da leprose tipo nuclear (CiLV-N): Andradas (MG) e São Roque (SP). Fitopatol Bras 39: 139.

Chamberlain CJ. 1932. Methods in plant histology. Chicago, The University of Chicago Press, $416 \mathrm{p}$.

Colariccio A, Lovisolo A, Chagas CM, Galetti SR, Rossetti VE and Kitajima EW. 1995. Mechanical transmission and ultrastructural aspects of Citrus leprosis virus. Fitopatol Bras 20: 208-213.

CORTElAzZO AL. 2007. Caracterização celular e bioquímica de sementes. Campinas: UNICAMP, 13 p.

COUTTS RHA. 1978. Suppression of virus induced local lesions in plamolysed leaf tissue. Plant Sci Lett 12: 7785.

ESAU K. 1977. Plant anatomy. $2^{\text {nd }}$ ed., J Wiley \& Sons, New York, $767 \mathrm{p}$.

FAHN A. 1979. Secretory tissues in plants. New York, Academic Press, 302 p.

FAHN A. 1988. Secretory tissues in vascular plants. Transley review N. 14, New Phytol 108: 229-257.

FEUSSNER I AND WASTERnACK C. 2002. The lipoxygenase pathway. Annu Rev Plant Biol 53: 275-297.

FISHER DB. 1968. Protein staining of ribboned epon sections for light microscopy. Histochemie 16: 92-96.

Freitas-Astúa J, Kitajima EW, Bastianel M, Locali EC, Antonioli R AND Machado MA. 2004. Identification of Citrus leprosis virus - nuclear type (CiLV-N) in sweet orange in the State of Rio Grande do Sul. Virus Rev Res 9: 247.

Freitas-Astúa J, KitAJima EW, Locali EC, AntonioLi-Luizoni R, BASTIANEL M AND Machado MA. 2005. Further evidence to support that citrus leprosis virus - cytoplasmic and nuclear types - are different viruses. In: Annual Meeting of the American PhytopathoLOGICAl Society, Caribbean Division, XLV, Annals San Jose, APS, 93 p.

Freitas-Astúa J, Bastianel M, Locali-Fabris EC, Novelli VM, Basílio-Palmieri AC, Silva-PinhaTI AC, TARgon MLPN AND MaChado MA. 2007. Differentially expressed stress-related genes in the compatible Citrus-Citrus leprosis virus interaction. Genet Mol Biol 30: 980-990. 
Gedalovich E AND FAHN A. 1985. The development and ultrastructure of gum ducts in Citrus plants formed as a result of brown-rot gummosis. Protoplasma 127: 73-81.

Gilbertson RL AND LUCAS WJ. 1996. How do viruses traffic on the vascular highway? Trends Plant Sci 8: 250251.

JENSEN WA. 1962. Botanical histochemistry. San Francisco: W.H. Freeman, 408 p.

JOHANSEN DA. 1940. Plant microtechnique. New York: McGraw-Hill, 523 p.

KARNOVSKY MJ. 1965. A formaldehyde-glutaraldehyde fixative of high osmolality for use in electron microscopy. J Cell Biol 27: 137-138.

Kitajima EW, Muller GW, Costa AS and Yuki W. 1972. Shot, rod-like particles associated with Citrus leprosis. Virology 50: 254-258.

Kitajima EW, Chagas CM And Rodrigues JCV. 2003. Brevipalpus transmitted plant virus and virus-like diseases: cytopathology and some recent cases. Exp Appl Acarol 30: 135-160.

Kitajima EW, Ferreira PTO And Freitas-Astúa J. 2004. Ocorrência da leprose dos citros, tipo nuclear (CiLV-N), nos municípios paulistas de Monte Alegre do Sul e Amparo. Summa Phytopathol 30: 68.

Kondo H, Maeda T, Shirako Y And TAmada T. 2006. Orchid fleck virus is a rhabdovirus with an unusual bipartite genome. J Gen Virol 87: 2413-2421.

Kopito RR. 2000. Aggresomes, inclusion bodies and protein aggregation. Trends in Cell Biol 10: 524-530.

Locali-Fabris EC, Freitas-Astúa J, Souza AA, TAKita MA, Astúa-Monge G, Antonioli-Luizon R, Rodrigues V, TARgON MLPN AND MACHAdo MA. 2006. Complete nucleotide sequence, genomic organization and phylogenetic analysis of Citrus leprosis virus cytoplasmic type. J Gen Virol 87: 2721-2729.
MARQUes JPR, KitAJima EW, Freitas-Astua J AND AppezZATO-DA GlÓRIA B. 2007. Lesões foliares e de ramos de laranjeira-doce causadas pela leprose-dos-citros. Pesq Agropec Bras 42: 1531-1536.

OPARKA KJ. 1994. Plasmolysis: new insight into old process. Transley review N. 67, New Phytol 126: 571-591.

PASCON RC ET AL. 2006. The complete nucleotide sequence and genomic organization of Citrus leprosis associated virus, cytoplasmic type (CiLV-C). Virus Genes 32: 289298.

PEARSE AGE. 1968. Histochemistry, theoretical and applied. $3^{\text {rd }}$ ed., London, Churchill, Vol. 1, 998 p.

Rodrigues FA, Benhamou N, LAWrence ED, JeFFREY BJ AND BÉLANGER RR. 2003a. Ultrastructural and cytochemical aspects of silicon-mediated rice blast resistance. Phytopathol 93: 535-546.

Rodrigues JVC, Kitajima EW, Childers CC, CHAGas CM and Machado MA. 2003b. Citrus leprosis. Exp Appl Acarol 30: 161-179.

Roussouw DJ AND SMith AJ. 1963. The relation of Calacarus citrifolii Keifer to concentric ring blotch of citrus. S Afr Citrus J 354: 7-9.

SAKAI WS. 1973. Simple method for differential staining of paraffin embedded plant material using toluidine blue $\mathrm{O}$. Stain Technol 48: 247-249.

SCHNEIDER H. 1968. Anatomy of Citrus. In: REUTHER W (Ed), The citrus industry. Univ Calif Div Agr Sci, Berkeley, Vol. 2, p. 1-85.

SHAн J. 2005. Lipids, lipases, and lipid-modifying enzymes in plant disease resistance. Annu Rev Phytopathol 43: 229-260. 